\title{
Badania możliwości zastosowania materiałów obciążających do wspomagania oczyszczania wód złożowych
}

\author{
Research on the possibility of using loading materials to support the treatment \\ of reservoir waters
}

\author{
Andrzej Janocha, Dorota Kluk \\ Instytut Nafty i Gazu - Państwowy Instytut Badawczy
}

\begin{abstract}
STRESZCZENIE: W artykule zaprezentowano zagadnienia związane z oczyszczaniem wód złożowych z zawiesin i osadów. W prowadzonych badaniach szczególny nacisk położono na techniki stosowania materiałów obciążeniowych w procesie oczyszczania wód. Materiałem badawczym były cztery rodzaje wód złożowych, które pobrano z separatorów odwiertów eksploatujących złoża gazu ziemnego. Wody te charakteryzowały się wysokimi zawartościami zawiesin $\left(76-176 \mathrm{mg} / \mathrm{dm}^{3}\right)$ oraz zróżnicowanym stopniem mineralizacji. Zawartość substancji rozpuszczonych oznaczono w granicach od $401 \mathrm{mg} / \mathrm{dm}^{3}$ do $306428 \mathrm{mg} / \mathrm{dm}^{3}$. Wydobyte wody złożowe w chwili obecnej zagospodarowane są najczęściej poprzez zatłoczenie ich do horyzontów chłonnych w wyeksploatowanych złożach węglowodorów. Przygotowanie wód do zatłoczenia ogranicza się jedynie do usunięcia łatwo opadających stałych cząstek i zawiesin obecnych w wydobywanych wodach złożowych. Porowatość i przepuszczalność skał złożowych determinuje rozmiary cząstek stałych obecnych w wodzie, które mogą zostać wtłoczone do wolnych przestrzeni w ośrodku porowatym. W procesie oczyszczania wód na drodze koagulacji i flokulacji, prowadzonych w warunkach laboratoryjnych, jako koagulant zastosowano Flokor ASW, natomiast flokulant stanowił Stabpol. Osady pokoagulacyjne charakteryzują się wysokim uwodnieniem, w związku z czym ich gęstość jest zbliżona do gęstości wody, w wyniku czego sedymentacja cząstek osadów wymaga długiego czasu. W celu zwiększenia szybkości sedymentacji cząstek zawartych w oczyszczanych wodach do roztworów wprowadzano kolejno materiały balastujące, którymi były piasek kwarcowy oraz preparaty bentonitowe: bentonit pylisty i preparat bentonitowy DuoBent 1 . Efektywność procesu oczyszczania wód oceniano, porównując stopień zmętnienia roztworu nad osadem przed i po dodaniu różnej ilości koagulantu, flokulantu i materiałów balastujących osady. Pomiar mętności badanych roztworów umożliwia oszacowanie zawartości w nich zawiesin i koloidów. Przeprowadzono badania laboratoryjne w zakresie możliwości wykorzystania wybranych materiałów balastujących zawiesiny w procesie oczyszczania wód złożowych. Określono efektywne dawki materiałów balastujących zalecanych do stosowania celem separacji zawiesin z wód złożowych. $\mathrm{W}$ artykule wykazano, że usuwanie zawiesin $\mathrm{z}$ wód złożowych można przeprowadzić z użyciem odpowiednio spreparowanego środka bentonitowego (DuoBent 1) bez wprowadzania dodatkowych substancji chemicznych. Dawki preparatu bentonitowego DuoBent 1 dozowane do wysokozmineralizowanych wód złożowych w celu usunięcia mętności są stosunkowo niewielkie. Wprowadzenie do oczyszczanych wód preparatu bentonitowego w ilościach powyżej $0,2 \mathrm{~g} / \mathrm{dm}^{3}$ powoduje uzyskanie wysokiej klarowności wody przeznaczonej do zatłaczania (mętność na poziomie 0-5 FAU). Wyniki przeprowadzonych badań mogą zostać wdrożone do praktycznego stosowania opisanej prostej metody oczyszczania wód złożowych przed zatłoczeniem do górotworu.
\end{abstract}

Słowa kluczowe: wody złożowe, oczyszczanie wód złożowych, substancje balastujące.

ABSTRACT: The article presents the issues related to of the removal of suspensions and sediments from reservoir waters. In the conducted research, particular emphasis was placed on the techniques of using loading materials in the water treatment process. The research materials were four types of reservoir water, which was collected from the separators of wells exploiting natural gas deposits. These waters were characterized by high suspended solids $\left(76-176 \mathrm{mg} / \mathrm{dm}^{3}\right)$ and a varied degree of mineralization. The content of dissolved substances was determined in the range from 401 to $306428 \mathrm{mg} / \mathrm{dm}^{3}$. The extracted reservoir waters are currently most often utilized by pumping into the absorbing horizons in depleted hydrocarbon reservoirs. The preparation of water for injection is limited only to the removal of easily settling solid particles and suspensions present in the extracted formation waters. The porosity and permeability of the deposit rocks determine the size of solid particles present in the water that can be forced into voids in the porous medium. In the process of water treatment by coagulation and flocculation, carried out in laboratory conditions, Flokor ASW was used as a coagulant, while Stabpol was used as a flocculant. Post-coagulation sludge is highly hydrated, so that its density is close to that of water, as a result of which sedimentation of sludge particles takes a long time. In order to increase the sedimentation rate of particles contained in the

Autor do korespondencji: D. Kluk, e-mail: andrzej.janocha@inig.pl

Artykuł nadesłano do Redakcji: 18.11.2020 r. Zatwierdzono do druku: 08.04.2021 r. 
treated waters, ballasting materials, which were quartz sand and bentonites: powdery bentonite and bentonite preparation DuoBent 1 , were successively introduced into the solutions. The effectiveness of the water treatment process was assessed by comparing the degree of turbidity of the solution above the sediment before and after adding a different amount of coagulant, flocculant and sedimentbalancing materials. The turbidity measurement of the tested solutions allows to estimate the content of suspensions and colloids in them. Laboratory tests were carried out on the possibility of using selected materials ballasting suspensions in the process of reservoir water treatment. Effective doses of ballast materials recommended for use in the separation of suspensions from formation waters were determined. Research results presented in this paper show that the removal of suspended solids from formation waters can be carried out with the use of a properly prepared bentonite agent (DuoBent 1) with no need of adding other chemical compounds. The doses of the DuoBent 1 bentonite preparation, dosed into highly mineralized reservoir waters in order to remove turbidity, are relatively small. Adding bentonite into the treated waters in amounts exceeding $0.2 \mathrm{~g} / \mathrm{dm}^{3}$ results in obtaining high clarity of the water intended for injection (turbidity at the level of 0-5 FAU). The results of the research can be implemented for practical use as a simple method of purifying reservoir water prior to injection into the formation.

Key words: reservoir waters, cleaning of reservoir waters, ballasting substances.

\section{Wprowadzenie}

Problemy związane z zagospodarowaniem wydobytych wód złożowych były jeszcze do niedawna praktycznie niezauważane przez przemysł górnictwa nafty i gazu. Wraz z zaostrzeniem przepisów dotyczących ochrony środowiska, ze wzrostem świadomości na temat powstających zagrożeń, a także z koniecznością zagospodarowania coraz większych objętości wód złożowych i związanymi z tym poważnymi kosztami - obserwuje się znaczący wzrost zainteresowania przemysłu zagadnieniami dotyczącymi możliwości zastosowania nowoczesnych metod i technik utylizacji solanek. Obecnie wody złożowe usuwane są z biosfery przede wszystkim poprzez zatłoczenie ich do nieproduktywnych horyzontów chłonnych w sczerpanych złożach węglowodorów. Proces ten, chociaż jest najbardziej ekonomiczny, może generować wysokie koszty, związane m.in. z kolmatacją strefy przyodwiertowej osadami zatłaczanymi wraz z wodą. Jednym ze sposobów przeciwdziałania temu niekorzystnemu zjawisku jest wstępne przygotowanie wód przed zatłoczeniem mające na celu usunięcie cząstek stałych w procesie koagulacji i sedymentacji osadów (Jakubowicz et al., 2008; Tzoupanos i Zouboulis, 2011; Jakubowicz i Steliga, 2017; Nadella et al., 2020).

Prawidłowe przeprowadzenie procesu koagulacji, a następnie oddzielenie osadów od wody w procesie sedymentacji oraz filtracji okazuje się w wielu przypadkach trudnym zadaniem. Osady pokoagulacyjne charakteryzują się wysokim uwodnieniem, w związku z czym ich gęstość jest zbliżona do gęstości wody, w wyniku czego sedymentacja cząstek osadów wymaga długiego czasu. Dodatkowo osady, które uległy sedymentacji, są bardzo podatne na reemisję (oderwanie od warstwy osadowej i przemieszczenie do warstwy wodnej), spowodowaną różnymi czynnikami, np. nawet niewielkim wzburzeniem wody, ruchami termicznymi czy ruchem wywołanym przez mieszanie wód o różnym zasoleniu (Bottero et al., 1990; Janocha i Kluk, 2005; Bache i Gregory, 2007; Tzoupanos i Zouboulis, 2011; Lee et al., 2012; Zhou et al., 2012). Z tego powodu stosowane są różne metody usprawnienia procesu sedymentacji, np. zmiana struktury osadów (flokulacja), skrócenie czasu sedymentacji poprzez wirowanie, filtrację na prasach filtracyjnych itp.

Jedną $\mathrm{z}$ takich metod usprawnienia procesu usuwania zanieczyszczeń z wody jest zastosowanie materiałów obciążeniowych (balastujących), powodujących korzystną zmianę polegającą na zwiększeniu gęstości osadów pokoagulacyjnych i znaczącym przyspieszeniu procesu sedymentacji (Jarvis et al., 2009; Gorin et al., 2015; Zhang et al., 2020).

Zastosowanie materiałów obciążeniowych, chociaż jest techniką dość obiecującą, nie jest szeroko praktykowane w przemyśle i wymaga prowadzenia badań laboratoryjnych w celu opracowania podstawowych założeń procesu. Większość opisywanych w literaturze badań ze środkami balastującymi dotyczy ścieków komunalnych i uzdatniania wody pitnej jako dodatkowego procesu w klasycznych metodach koagulacji i flokulacji (Desjardins et al., 2002; Young i Edwards, 2003; Gasperi et al., 2012; Lapointe i Barbeau, 2016; Zafisah et al., 2020).

Zacytowane badania dowodzą, że istnieje optymalna ilość środka balastującego, związana $\mathrm{z}$ wieloma czynnikami, np.: mętnością wody surowej, wielkością dawek koagulantu i flokulantu. Można oczekiwać, że właściwa do zastosowania dawka będzie zmieniać się w zależności od rodzaju parametrów oczyszczanej wody. Korzyściami płynącymi z dodatku do procesu koagulacji i flokulacji środka obciążającego jest uzyskanie wyższych szybkości sedymentacji.

Środkami obciążeniowymi mogą być: piasek krzemionkowy, piasek granitowy i piasek magnetytowy, antracyt, szkło, mączka bazaltowa. Na uwagę zasługują także bentonit i preparaty wykonane na jego bazie (Kim et al., 1982; Al Dwairi i Al-Rawajfeh, 2012; Jahed et al., 2014).

Wykorzystanie naturalnych skał i minerałów ilastych, takich jak bentonit i zeolity, do oczyszczania wody i ścieków staje się coraz częstsze ze względu na ich powszechność występowania, niską cenę i możliwości adsorpcyjne, a także wymianę jonową, która jest wysoce zdolna do adsorbowania 
wszelkiego rodzaju zanieczyszczeń, w tym metali ciężkich występujących w wodach (Guimarães et al., 2009). Ta wyjątkowa zdolność wynika z obecności mineralnego montmorylonitu (Khenifi et al., 2009).

Bentonit to naturalny materiał zawierający niezbędne składniki, takie jak glin, żelazo i glinokrzemiany, które są przydatne do oczyszczania ścieków. Co więcej, bentonit jest bezpieczny dla środowiska przyrodniczego, jest również tańszy od innych możliwych do technologicznego zastosowania środków chemicznych (Al-Qunaibit et al., 2005). Wiele jednak dostępnych na rynku koagulantów opartych jest na substancjach chemicznych mogących niekorzystnie oddziaływać na otaczające środowisko (Ozcan et al., 2007).

W dobie szczególnego zainteresowania złożami węglowodorów opracowywane są technologie wspomagające efektywność ich wydobycia. Do takich technologii zaliczyć należy metody wtórnego oddziaływania na złoża ropy naftowej, do których należy między innymi jego nawadnianie poprzez zatłoczenie do górotworu wody, w wyniku czego następuje wypieranie ropy naftowej z porów skały. Technologia ta może być realizowana jako powrotne zatłaczanie wód złożowych (Lubaś, 2013). Wody takie jednak przed zatłoczeniem do górotworu muszą spełniać określone kryteria jakości.

Zasadniczo także inny jest cel oczyszczania ścieków komunalnych i wody pitnej niż wód złożowych. Różne są też wyjściowe składy i właściwości opisywanych w literaturze oczyszczanych wód w stosunku do wód złożowych. O ile w niniejszej pracy będzie można wykorzystać pewne doświadczenia metodologiczne z prowadzonych eksperymentów, to do realizacji celu pracy należy przeprowadzić indywidualne badania dla oczyszczanych wód złożowych.

\section{Materiał i metodyka badawcza}

Materiał badawczy stanowiły wody złożowe wydzielone w separatorach odwiertów pracujących na obszarze Niżu Polskiego: Ł-1, K-18H, J-8K, ŚW-4, L-1. Odwiertami tymi prowadzona jest eksploatacja złóż gazu ziemnego.

Badane wody poddano analizom fizyczno-chemicznym, których wyniki zamieszczono w tabeli 1 . Na podstawie otrzymanych rezultatów wykonano charakterystykę badanych wód złożowych ze szczególnym uwzględnieniem zawartości składników i oznaczonych parametrów (odczyn, potencjał oksydacyjno-redukcyjny) sprzyjających niepożądanym procesom złożowym.

Analizy fizyczne i chemiczne prowadzono z wykorzystaniem aparatury: $\mathrm{pH}-\mathrm{metr} 330 \mathrm{i}(\mathrm{pH}$, potencjał oksydacyjno-redukcyjny), fotometr Lovibond ${ }^{\circledR}$ Max Direct (mętność), waga analityczna Radwag WAA 220/C/2 (substancje rozpuszczone i nierozpuszczone), fotometr Hach Lange DR 3900 (SPCz anionowe, SPCz niejonowe), spektrofotometr UV/VIS Lambda 35 (siarczki, siarczany, żelazo, bar, stront).

W kolejnym etapie badań badane wody poddano procesowi oczyszczenia na drodze koagulacji, w wyniku której następowała destabilizacja koloidów, a później tworzenie się rozbudowanych aglomeratów (flokulacja). W procesie oczyszczania wód na drodze koagulacji i flokulacji prowadzonych w warunkach laboratoryjnych jako koagulant zastosowano Flokor ASW, natomiast flokulant stanowił Stabpol. W celu zwiększenia szybkości sedymentacji cząstek zawartych w oczyszczanych wodach do roztworów wprowadzano kolejno materiały balastujące (każdy oddzielnie), którymi były piasek kwarcowy o wielkości ziaren $0,05-0,18 \mathrm{~mm}$ oraz preparaty bentonitowe: bentonit pylisty i preparat bentonitowy DuoBent 1 .

Proces koagulacji i flokulacji oczyszczanych wód prowadzono przy użyciu czterostanowiskowego koagulatora laboratoryjnego (rys. 1) z regulowaną szybkością obrotów. Koagulator ten wyposażony był w cztery zsynchronizowane i podnoszone mieszadła, elektroniczną regulację szybkości obrotów, elektroniczną nastawę czasu mieszania i zegar odliczający czas do zakończenia mieszania, a także podświetlaną tylną ściankę, ułatwiającą obserwację przebiegu procesu. Proces koagulacji prowadzono przy stałym czasie szybkiego mieszania, wynoszącym $5 \mathrm{~min}$ (przy $200 \mathrm{obr} / \mathrm{min}$ ), następnie $5 \mathrm{~min}$ przy $60 \mathrm{obr} / \mathrm{min}$ i $5 \mathrm{~min}$ wolnego mieszania $(15 \mathrm{obr} / \mathrm{min})$. W pierwszym okresie koagulanty, flokulanty i substancje balastowe rozprowadzone w całej objętości zlewki ulegają zhydrolizowaniu oraz nawiązują kontakt z cząsteczkami stałymi zawieszonymi w roztworze wodnym. Następnie w okresie wolniejszego mieszania cząsteczki koloidalne obecne w roztworze, zderzając się ze sobą, łączą w większe agregaty, które szybko sedymentują.

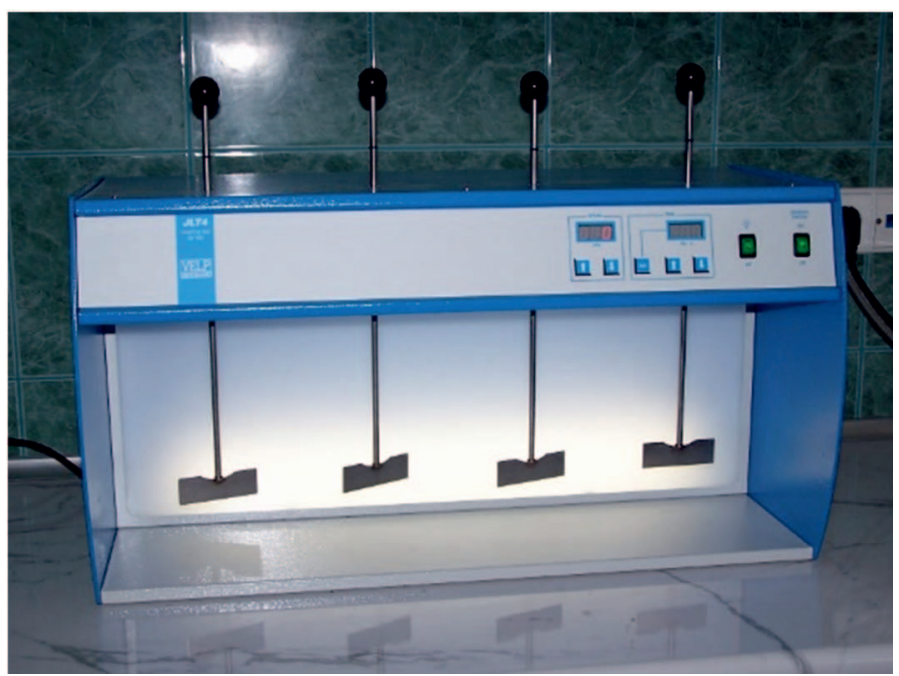

Rys. 1. Laboratoryjny koagulator czterostanowiskowy

Fig. 1. Laboratory 4-station coagulator 
Efektywność procesu oczyszczania wód oceniano, porównując stopień zmętnienia roztworu nad osadem przed i po dodaniu różnej ilości koagulantu, flokulantu i materiałów balastujących osady. Mętność roztworu jest wywołana obecnością zawiesin i koloidów, dlatego pomiar mętności może być stosowany do kontroli skuteczności ich usuwania z roztworu.

\section{Charakterystyka wód złożowych}

Wyniki fizycznych i chemicznych analiz próbek wód złożowych, które przedstawiono w tabeli 1, wskazują na ich znaczne zróżnicowanie. Odczyn badanych wód zawiera się w zakresie $\mathrm{pH}, \mathrm{tj}$. od 4,1 (J-8K) do $5,9(\mathrm{~K}-18 \mathrm{H})$, a wartości potencjałów oksydacyjno-redukcyjnych Eh oznaczono na niskim poziomie (od $-108 \mathrm{mV}$ do $-128,4 \mathrm{mV}$ ), charakteryzującym warunki redukcyjne.

Związki żelaza i manganu w wodach podziemnych występują $\mathrm{w}$ formie zredukowanej. Na skutek zmian parametrów fizycznych i chemicznych wód, będących wynikiem zarówno procesów związanych z wydobyciem i magazynowaniem, jak i powrotnym zatłoczeniem wód do złoża (zmiany ciśnienia, temperatury, rozgazowanie, zmiany potencjału oksydacyjno-redukcyjnego, $\mathrm{pH}$, a także dodatek różnych substancji chemicznych), mogą tworzyć zawiesiny i roztwory koloidalne (Gantzer et al., 2009; Kluk, 2011; Córdoba et al., 2016; Johnson et al., 2018; Ahmad et al., 2019; Koppenol i Hider, 2019). We wszystkich analizowanych wodach separatorowych istnieje zagrożenie wytrącania osadów, wynikające z obecności żelaza i manganu. Jony tych metali w badanych wodach występują w ilościach: Fe: 18,1-149,4 mg/dm³ ${ }^{3}, \mathrm{Mn}$ : $3,91-8,18 \mathrm{mg} / \mathrm{dm}^{3}$. Literatura podaje, że nawet niewielkie zmiany wartości potencjału oksydacyjno-redukcyjnego w wodzie mogą prowadzić do wytrącenia się związków żelaza i manganu (Hem, 1989; Munger et al., 2016; Kluk, 2020).
Omawiane wody charakteryzują się zróżnicowanym stopniem mineralizacji. Zawartość substancji rozpuszczonych oznaczono w granicach od $401 \mathrm{mg} / \mathrm{dm}^{3}$ do $306428 \mathrm{mg} / \mathrm{dm}^{3}$, przy czym najwyższą wartość odnotowano w wodzie z odwiertu Ł-1. Rozkład zawartości jonów chlorkowych, wapnia i magnezu koresponduje ze stopniem zmineralizowania analizowanych wód. Najwyższe zawartości tych jonów odnotowano w płynach o najwyższym stopniu mineralizacji.

Udział zawiesin w badanych wodach złożowych kształtuje się na wysokim poziomie $\left(76-176 \mathrm{mg} / \mathrm{dm}^{3}\right)$. Ponadto w badanych wodach oznaczono wysokie wartości wskaźnika

Tabela 1. Wyniki analiz fizycznych i chemicznych badanych wód złożowych

Table 1. Results of physical and chemical analyses of the investigated reservoir waters

\begin{tabular}{|c|c|c|c|c|c|}
\hline Oznaczenia & Jednostka & L-1 & K-18H & J 8K & ŚW-4 \\
\hline $\mathrm{pH}$ & & 4,8 & 5,9 & 4,1 & 5,0 \\
\hline Eh & $\mathrm{mV}$ & $-117,8$ & $-108,0$ & $-116,0$ & $-128,4$ \\
\hline Mętność & FAU & 400 & 238 & 366 & 450 \\
\hline Gęstość $\left(20^{\circ} \mathrm{C}\right)$ & $\mathrm{g} / \mathrm{cm}^{3}$ & 1,182 & 0,997 & 1,194 & 1,170 \\
\hline Sucha pozostałość & $\mathrm{mg} / \mathrm{dm}^{3}$ & 306428 & 401 & 286316 & 245604 \\
\hline Pozostałość po prażeniu & $\mathrm{mg} / \mathrm{dm}^{3}$ & 288904 & 98 & 271800 & 239600 \\
\hline Zawiesina ogólna & $\mathrm{mg} / \mathrm{dm}^{3}$ & 159 & 76 & 140 & 176 \\
\hline $\mathrm{ChZT}_{(\mathrm{Cr})}$ & $\mathrm{mg} \mathrm{O}_{2} / \mathrm{dm}^{3}$ & 13589 & 15023 & 33124 & 41256 \\
\hline $\mathrm{BZT}_{5}$ & $\mathrm{mg} \mathrm{O}_{2} / \mathrm{dm}^{3}$ & 2258 & 1875 & 6875 & 10256 \\
\hline OWO & $\mathrm{mg} / \mathrm{dm}^{3}$ & 1059 & 1004 & 2947 & 5895 \\
\hline TPH & $\mathrm{mg} / \mathrm{dm}^{3}$ & 284 & 64 & 39 & 25 \\
\hline SPCz anionowe & $\mathrm{mg} / \mathrm{dm}^{3}$ & 18,9 & 1,23 & 17,5 & 13,5 \\
\hline SPCz niejonowe & $\mathrm{mg} / \mathrm{dm}^{3}$ & 1,73 & 247 & 13,8 & 54,3 \\
\hline Zawartość chlorków $\mathrm{Cl}^{-}$ & $\mathrm{mg} / \mathrm{dm}^{3}$ & 166615 & 91 & 169250 & 159523 \\
\hline Zawartość siarczanów $\mathrm{SO}_{4}{ }^{2-}$ & $\mathrm{mg} / \mathrm{dm}^{3}$ & 189 & 4,3 & 71 & 44 \\
\hline $\begin{array}{l}\text { Zawartość wodorowęglanów } \\
\mathrm{HCO}_{3}^{-}\end{array}$ & $\mathrm{mg} / \mathrm{dm}^{3}$ & 169 & 215 & n.s. & n.s. \\
\hline Zawartość bromków $\mathrm{Br}^{-}$ & $\mathrm{mg} / \mathrm{dm}^{3}$ & 249,3 & 4,12 & 2785 & 1689 \\
\hline Zawartość sodu $\mathrm{Na}^{+}$ & $\mathrm{mg} / \mathrm{dm}^{3}$ & 93841 & 61,9 & 34125 & 52268 \\
\hline Zawartość potasu $\mathrm{K}^{+}$ & $\mathrm{mg} / \mathrm{dm}^{3}$ & 588 & 28,6 & 2010 & 2914 \\
\hline Zawartość wapnia $\mathrm{Ca}^{2+}$ & $\mathrm{mg} / \mathrm{dm}^{3}$ & 35258 & 18,6 & 36874 & 33610 \\
\hline Zawartość magnezu $\mathrm{Mg}^{2+}$ & $\mathrm{mg} / \mathrm{dm}^{3}$ & 4974 & 12,7 & 5105 & 2917 \\
\hline Zawartość żelaza $\mathrm{Fe}_{\text {og. }}$ & $\mathrm{mg} / \mathrm{dm}^{3}$ & 75,9 & 18,1 & 149,43 & 92,93 \\
\hline Zawartość manganu $\mathrm{Mn}^{2+}$ & $\mathrm{mg} / \mathrm{dm}^{3}$ & 7,05 & 3,91 & 6,89 & 8,187 \\
\hline Zawartość miedzi $\mathrm{Cu}$ & $\mathrm{mg} / \mathrm{dm}^{3}$ & 0,009 & 0,021 & 01,42 & 0,698 \\
\hline Zawartość ołowiu Pb & $\mathrm{mg} / \mathrm{dm}^{3}$ & 0,035 & 0,068 & 3,247 & 6,781 \\
\hline Zawartość cynku Zn & $\mathrm{mg} / \mathrm{dm}^{3}$ & 0,358 & 0,651 & 25,478 & 22,589 \\
\hline Zawartość niklu Ni & $\mathrm{mg} / \mathrm{dm}^{3}$ & 0,129 & 0,067 & 0,984 & 0,184 \\
\hline Zawartość kobaltu Co & $\mathrm{mg} / \mathrm{dm}^{3}$ & 0,028 & 0,009 & 0,039 & 0,081 \\
\hline Zawartość kadmu Cd & $\mathrm{mg} / \mathrm{dm}^{3}$ & 0,048 & 0,003 & 0,058 & 0,021 \\
\hline Zawartość strontu Sr & $\mathrm{mg} / \mathrm{dm}^{3}$ & 3012 & 0,061 & 2459 & 2458 \\
\hline Zawartość baru $\mathrm{Ba}$ & $\mathrm{mg} / \mathrm{dm}^{3}$ & 81 & 0,038 & 123 & 257 \\
\hline Zawartość krzemu Si & $\mathrm{mg} / \mathrm{dm}^{3}$ & 4,26 & 3,18 & 5,12 & 4,59 \\
\hline Zawartość glinu Al & $\mathrm{mg} / \mathrm{dm}^{3}$ & 0,056 & 0,061 & 0,128 & 0,092 \\
\hline
\end{tabular}


zapotrzebowania tlenu $\left(\mathrm{ChZT}_{(\mathrm{Cr})} ; 13589-41256 \mathrm{mg} \mathrm{O}_{2} / \mathrm{dm}^{3}\right)$, co potwierdza redukcyjne warunki w badanych wodach, wyrażone ujemnymi potencjałami Eh. We wszystkich badanych wodach oznaczono anionowe i niejonowe środki powierzchniowo czynne.

Przeprowadzone analizy fizyczne i chemiczne wód pobranych z separatorów poszczególnych odwiertów wykazały, że ich jakość zależy zarówno od charakterystyki kolektora akumulującego złoża węglowodorów, z którego zostały wydobyte, jak i od środków chemicznych wprowadzanych do płynów złożowych mających na celu usprawnienie eksploatacji poszczególnych złóż.

\section{Badanie moźliwości zastosowania wybranych substancji w procesie oczyszczania wód złożowych}

Proces oczyszczania wód złożowych na drodze koagulacji i flokulacji rozpoczęto od doboru optymalnych dawek koagulantu, flokulantu oraz substancji obciążających osady, którymi były bentonit pylisty oraz piasek kwarcowy. Etap ten prowadzono z wykorzystaniem wody złożowej Ł-1. Dawki wprowadzanych do oczyszczanej wody substancji przedstawiono w tabeli 2.
W wyniku przeprowadzenia testów oczyszczania na drodze koagulacji i flokulacji wody złożowej z odwiertu $~-1$ - uzyskano obniżenie mętności z początkowej wartości $400 \mathrm{FAU}$ do zakresu 50-55 FAU, zależnie od dawki zastosowanego koagulantu (Flokor ASW). Nieco gorszy efekt oczyszczenia wody (65-85 FAU) otrzymano w przypadku prowadzenia procesu koagulacji i flokulacji, podczas którego w końcowym etapie do roztworu wprowadzono substancje obciążające (bentonit pylisty i piasek kwarcowy) (tabele 1 i 2 ).

W związku z powyższym przeprowadzono próby dotyczące badania wpływu granulacji materiałów obciążeniowych na efektywność procesów oczyszczania, co było możliwe dla piasku kwarcowego. W wyniku wykonanych badań nie stwierdzono zasadniczej różnicy dla frakcji piasku 108-140 $\mu \mathrm{m}$ i 140-180 $\mu \mathrm{m}$, natomiast frakcja $180-320 \mu \mathrm{m}$ znacząco pogorszyła wyniki sedymentacji (mętność > 130 FAU). Zaobserwowano, że nadmierne dozowanie piasku (powyżej $0,4 \mathrm{~g} / 300 \mathrm{~cm}^{3}$ ) oraz większa granulacja powodowały przedwczesne tworzenie flokut, które szybko sedymentowały, pogarszając efekt usuwania zawiesin. Stwierdzono, że jakość i ilość balastowanego środka wpływa na proces koagulacji/flokulacji, a następnie na usuwanie zawieszonych ciał stałych.

W związku z powyższym w kolejnym etapie ukierunkowano badania na możliwość modyfikacji powierzchni

Tabela 2. Wpływ rodzaju i dawki koagulantu, flokulantu oraz materiałów balastujących (bentonit pylisty, piasek kwarcowy) wprowadzanych do wody złożowej Ł-1 na efekt jej oczyszczenia

Table 2. Influence of the type and dose of coagulant, flocculant and ballast substances (powdery bentonite, quartz sand) introduced into the water reservoir $\mathrm{L}-1$ on the effect of its purification

\begin{tabular}{|l|c|c|c|c|c|}
\hline \multirow{2}{*}{ Rodzaj dodatku } & \multirow{2}{*}{ Jednostka } & \multicolumn{4}{c|}{ Dawka dozowanej substancji do 300 cm cmody zlożowej $^{3}$} \\
\cline { 3 - 6 } & & zlewka nr 1 & zlewka nr 2 & zlewka nr 3 & zlewka nr 4 \\
\hline \hline Flokor ASW & $\mathrm{cm}^{3}$ & 10 & 15 & 10 & 10 \\
\hline Stabpol $(0,5 \%)$ & $\mathrm{cm}^{3}$ & 0,3 & 0,3 & 0,3 & 0,3 \\
\hline Bentonit pylisty & $\mathrm{g}$ & - & - & 0,64 & - \\
\hline Piasek kwarcowy $180 \mu \mathrm{m}$ & $\mathrm{g}$ & - & - & - & 0,40 \\
\hline Mętność wody po procesie oczyszczania & FAU & 55 & 50 & 65 & 85 \\
\hline
\end{tabular}

Tabela 3. Wpływ rodzaju i dawki koagulantu, flokulantu oraz materiałów balastujących (DuoBent 1, prażony piasek, prażony bentonit pylisty) wprowadzanych do wody złożowej Ł-1 na efekt jej oczyszczenia

Table 3. Influence of the type and dose of coagulant, flocculant and ballast substances (DuoBent 1, roasted sand, roasted powdery bentonite) introduced into the water reservoir $\mathrm{L}-1$ on the effect of its purification

\begin{tabular}{|l|c|c|c|c|c|}
\hline \multirow{2}{*}{ Rodzaj dodatku } & \multirow{2}{*}{ Jednostka } & \multicolumn{3}{c|}{ Dawka dozowanego skladnika do $\mathbf{3 0 0} \mathbf{~ c m}^{\mathbf{3}}$ wody zlożowej } \\
\cline { 3 - 6 } & & zlewka nr 1 & zlewka nr 2 & zlewka nr 3 & zlewka nr 4 \\
\hline \hline Flokor ASW & $\mathrm{cm}^{3}$ & 3 & 3 & 3 & 3 \\
\hline Stabpol $(0,5 \%)$ & $\mathrm{cm}^{3}$ & 0,3 & 0,3 & 0,3 & 0,3 \\
\hline Preparat DuoBent 1 & $\mathrm{g}$ & - & - & 0,64 & - \\
\hline Prażony piasek $140 \mu \mathrm{m}$ & $\mathrm{g}$ & - & - & - & 0,4 \\
\hline Prażony bentonit pylisty & $\mathrm{g}$ & - & 0,3 & - & - \\
\hline Mętność & FAU & 51 & 50 & 0 & 75 \\
\hline
\end{tabular}


materiałów obciążeniowych dla zwiększenia efektywności oczyszczania wód. W tym celu do oczyszczanej wody (Ł-1) wprowadzano substancje balastujące, takie jak: preparat bentonitowy DuoBent 1 oraz wyprażone piasek krzemionkowy i bentonit pylisty. Obróbka termiczna bentonitu pylistego i frakcji piasku $108-140 \mu \mathrm{m}$ polegała na poddaniu ich prażeniu $\mathrm{w}$ temperaturze $350^{\circ} \mathrm{C}$ celem zmniejszenia zawartości wody hydratacyjnej.

Dokonane dotąd obserwacje i pomiary mętności wody po zakończeniu sedymentacji w poszczególnych seriach testów uzasadniły prowadzenie procesu oczyszczania wody złożowej na drodze koagulacji połączonej z flokulacją przy obniżonych dawkach koagulantu w obecności środków balastujących. Skład poszczególnych komponentów wprowadzanych do oczyszczanej wody przedstawiono w tabeli 3, natomiast wynik testów zobrazowano na rysunku 2.

Na podstawie wyników przeprowadzonych badań stwierdzono, że preparat DuoBent 1 jest najlepszą substancją ułatwiającą sedymentację zawiesin w badanej wodzie złożowej z odwiertu Ł-1 (tab. 3, rys. 2). Kolejne badania wykonano więc celem minimalizacji dawek flokulantu i koagulantu oraz doboru optymalnej dawki preparatu DuoBent 1. W tabeli 4 przedstawiono rodzaj i dawki wprowadzanych do oczyszczanej wody substancji oraz efekt jej oczyszczenia.

Wyniki przeprowadzonego testu wskazują na to, że wszystkie próbki oczyszczanej wody są dobrze sklarowane, a w próbce o najmniejszej dawce preparatu DuoBent 1 osiągnięto najlepszy rezultat (100\% redukcji mętności). Wyniki testu skłoniły do przeprowadzenia badań procesu oczyszczania wody, w którym zrezygnowano z dawkowania koagulantu

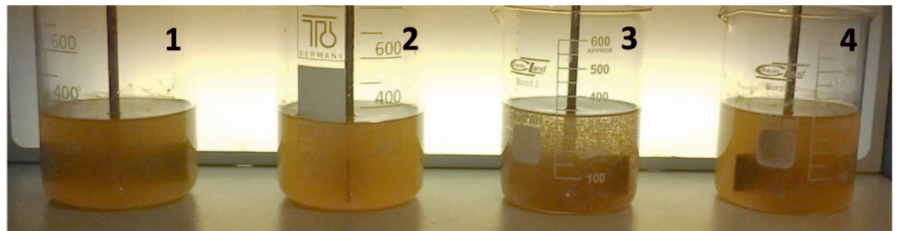

Testowana woda po zakończeniu procesu mieszania $15 \mathrm{obr} / \mathrm{min}$

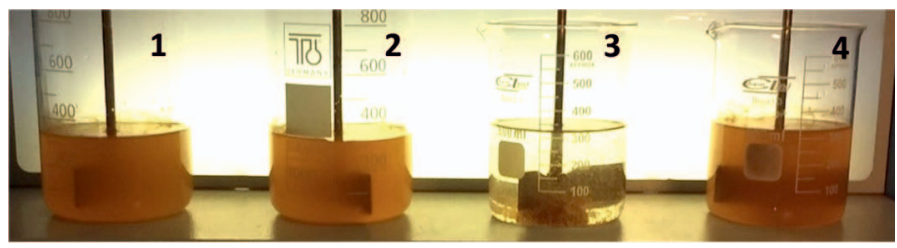

Testowana woda po zakończeniu procesu mieszania $60 \mathrm{obr} / \mathrm{min}$

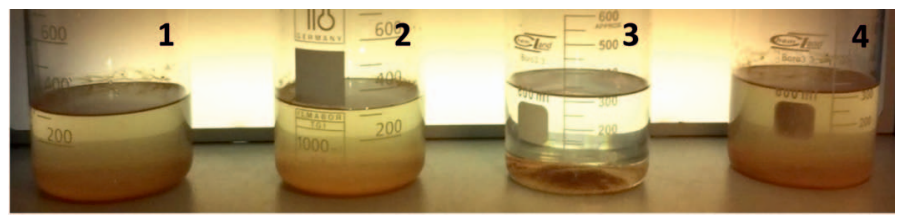

Testowana woda po zakończeniu procesu mieszania

Rys. 2. Obraz poszczególnych etapów oczyszczania wody złożowej z odwiertu $\mathrm{L}-1$

Fig. 2. Photo of individual stages of water treatment from the $\mathrm{L}-1$ well

i flokulantu, ponadto zmniejszono stężenie preparatu bentonitowego DuoBent 1 (tab. 5). Rezultaty zobrazowano na rysunku 3.

Na podstawie wykonanych badań (tab. 5, rys. 3) wykazano, że proces oczyszczania wody można zrealizować poprzez wprowadzenie do roztworu odpowiedniej dawki preparatu bentonitowego DuoBent 1 jako materiału balastującego zawiesiny zawarte w oczyszczanej wodzie złożowej.

Tabela 4. Wpływ rodzaju i dawki koagulantu, flokulantu oraz materiału balastującego (DuoBent 1) wprowadzanych do wody złożowej Ł-1 na efekt jej oczyszczenia

Table 4. Influence of the type and dose of coagulant, flocculant and ballast substances (DuoBent 1) introduced into the water reservoir $€-1$ on the effect of its purification

\begin{tabular}{|l|c|c|c|c|c|}
\hline \multirow{2}{*}{ Rodzaj dodatku } & \multirow{2}{*}{ Jednostka } & \multicolumn{4}{|c|}{ Dawka dozowanego składnika do $\mathbf{3 0 0} \mathbf{~ c m}^{3}$ wody złożowej } \\
\cline { 3 - 6 } & & zlewka nr 1 & zlewka nr 2 & zlewka nr 3 & zlewka nr 4 \\
\hline \hline Flokor ASW & $\mathrm{cm}^{3}$ & 1 & 1 & - & - \\
\hline Stabpol 0,5\% & $\mathrm{cm}^{3}$ & 0,2 & - & - & - \\
\hline Bentonit DuoBent 1 & $\mathrm{g}$ & 0,515 & 0,550 & 0,270 & 0,574 \\
\hline Mętność & FAU & 2 & 2 & 0 & 2 \\
\hline
\end{tabular}

Tabela 5. Wpływ dawki materiału balastującego wprowadzanego do wody złożowej Ł-1 na efekt jej oczyszczenia

Table 5. Influence of the dose of ballast substance introduced into the $€-1$ reservoir water on the effect of its purification

\begin{tabular}{|l|c|c|c|c|c|}
\hline \multirow{2}{*}{ Rodzaj dodatku } & \multirow{2}{*}{ Jednostka } & \multicolumn{3}{|c|}{ Dawka dozowanego skladnika do 300 cm$^{\mathbf{3}}$ wody zlożowej } \\
\cline { 3 - 6 } & & zlewka nr 1 & zlewka nr 2 & zlewka nr 3 & zlewka nr 4 \\
\hline \hline Bentonit DuoBent 1 & $\mathrm{g}$ & 0,0237 & 0,0563 & 0,0902 & 0,1842 \\
\hline Mętność & FAU & 20 & 6 & 3 & 0 \\
\hline
\end{tabular}




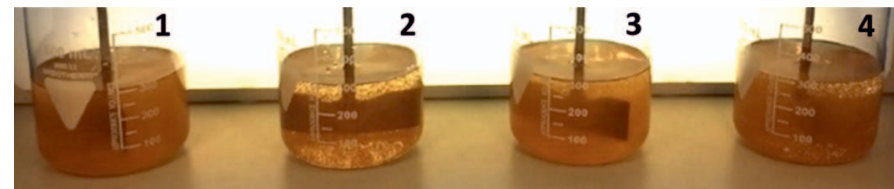

Testowana woda $\mathrm{w}$ trakcie procesu mieszania $60 \mathrm{obr} / \mathrm{min}$

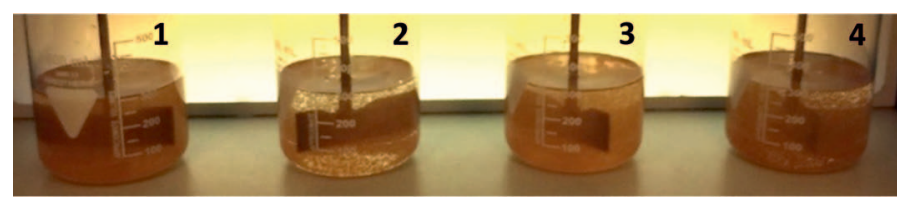

Testowana woda $\mathrm{w}$ trakcie procesu mieszania $15 \mathrm{obr} / \mathrm{min}$

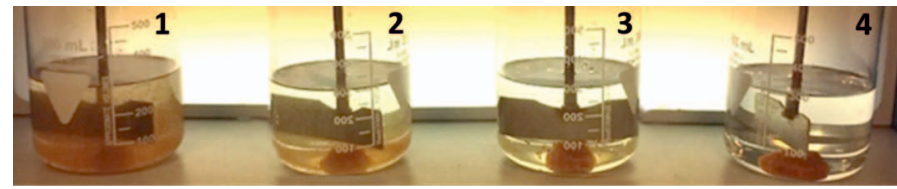

Testowana woda po zakończeniu procesu mieszania

Rys. 3. Efekt oczyszczenia wody złożowej z odwiertu $Ł-1$

Fig. 3. The effect of cleaning of formation water from the $\measuredangle-1$ well

W kolejnym etapie badań przeprowadzono testy oczyszczania wody złożowej pochodzącej z odwiertu K-18H. Wyniki badań przedstawiono w tabeli 6 . $Z$ danych tych wynika, że dodatek koagulantu Flokor ASW (zlewka nr 2) spowodował pogorszenie efektu klarowania wody, co było przesłanką do zaniechania jego dawkowania w kolejnej serii prowadzonych testów. W związku z powyższym kolejne badania wykonano pod kątem doboru optymalnej dawki preparatu bentonitowego DuoBent 1 celem klarowania wody złożowej K-18H. Efektem prowadzonych badań dotyczących usuwania zanieczyszczeń w postaci zawiesin z wody złożowej odwiertu K-18H w obecności DuoBent 1 była redukcja jej mętności do poziomu 4-23 FAU przy dawkach preparatu bentonitowego DuoBent $1 \mathrm{w}$ zakresie 0,069-0,305 $\mathrm{g} / 300 \mathrm{~cm}^{3}$ badanej wody (tab. 6).

W związku z bardzo dobrym efektem usunięcia zawie$\sin \mathrm{z}$ roztworu na drodze koagulacji i flokulacji wspomaganej dodatkiem substancji balastującej, którą był preparat bentonitowy DuoBent 1, w kolejnych etapach testów przeprowadzono oczyszczanie wód złożowych z odwiertów J-8K oraz ŚW-4 z wykluczeniem stosowania koagulantu i flokulantu. Do oczyszczanej wody wprowadzono jedynie preparat bentonitowy DuoBent 1.

Podczas testów dotyczących możliwości usuwania zawiesin i osadów na drodze ich flokulacji prowadzonych dla wody złożowej z odwiertu J-8K wykazano, że zastosowanie dawek preparatu bentonitowego DuoBent $1 \mathrm{w}$ ilościach 0,0695-0,1600 g/300 cm wprowadzanych do oczyszczanej wody złożowej umożliwiło redukcję jej mętności do poziomu 14-0 FAU. Efekt oczyszczenia wody złożowej i ilość wprowadzanego preparatu bentonitowego DuoBent 1 przedstawiono w tabeli 6.

Kolejne testy wykonano celem usunięcia zawiesin i osadów z wody złożowej pobranej z odwiertu ŚW-4. Efekt oczyszczenia wody złożowej ŚW-4 w zależności od ilości wprowadzanego preparatu bentonitowego DuoBent 1 przedstawiono w tabeli 6 .

W badaniach ustalono, że optymalnym zakresem dawek preparatu bentonitowego DuoBent 1, którego dodatek do oczyszczanej wody powoduje istotną redukcję zawiesin, jest przedział $0,0166-0,1232 \mathrm{~g} / 300 \mathrm{~cm}^{3}$ wody złożowej. Z przedstawionych wyników można wyciągnąć wniosek, że przy zastosowaniu preparatu bentonitowego DuoBent $1 \mathrm{w}$ dawkach 0,0930-0,1232 g/300 $\mathrm{cm}^{3}$ oczyszczanej wody uzyskiwane jest-obniżenie jej mętności z wartości 450 FAU do zakresu 6-0 FAU (tab. 6).

Tabela 6. Efekt oczyszczania wód złożowych w zależności od rodzaju i dawki wprowadzanych dodatków

Table 6. The effect of purification of reservoir waters depending on the type and dose of the introduced additives

\begin{tabular}{|c|c|c|c|c|c|}
\hline \multirow{2}{*}{ Rodzaj dodatku } & \multirow{2}{*}{ Jednostka } & \multicolumn{4}{|c|}{ Dawka dozowanego składnika wprowadzana do $300 \mathrm{~cm}^{3}$ wody złożowej } \\
\hline & & zlewka nr 1 & zlewka nr 2 & zlewka nr 3 & zlewka nr 4 \\
\hline \multicolumn{6}{|c|}{ Woda zlożowa z odwiertu K-18H } \\
\hline Flokor ASW & $\mathrm{cm}^{3}$ & - & 1 & - & - \\
\hline Bentonit DuoBent 1 & g & 0,0616 & 0,056 & 0,0459 & 0,8977 \\
\hline Mętność & FAU & 17 & 78 & 27 & 0 \\
\hline Bentonit DuoBent 1 & $\mathrm{~g}$ & 0,069 & 0,100 & 0,153 & 0,305 \\
\hline Mętność & FAU & 23 & 11 & 7 & 4 \\
\hline \multicolumn{6}{|c|}{ Woda złożowa z odwiertu J-8K } \\
\hline Bentonit DuoBent 1 & $\mathrm{~g}$ & 0,0695 & 0,0974 & 0,1214 & 0,1600 \\
\hline Mętność & FAU & 14 & 7 & 4 & 0 \\
\hline \multicolumn{6}{|c|}{ Woda złożowa z odwiertu ŚW-4 } \\
\hline Bentonit DuoBent 1 & $g$ & 0,0166 & 0,0495 & 0,0930 & 0,1232 \\
\hline Mętność & FAU & 57 & 14 & 6 & 0 \\
\hline
\end{tabular}




\section{Efektywność oczyszczania wód z wykorzystaniem substancji balastujących osady}

Przeprowadzone badania w zakresie możliwości wykorzystania materiałów balastujących zawiesiny i osady zawarte w wodach złożowych wykazały celowość ich stosowania. Wprowadzenie do roztworu wód złożowych ziaren o dużej gęstości lub o dużych rozmiarach jako cząstek balastujących zawieszone w roztworze zawiesiny przyspiesza ich sedymentację. Efekt prowadzonych testów oceniano na podstawie różnic mętności wód złożowych przed i po dodaniu do nich substancji balastujących. Otrzymane wartości mętności przeliczono proporcjonalnie względem zawartości zawiesin zawartych w każdej z wód złożowych, otrzymując wartość wyrażoną w jednostce $\mathrm{mg} / \mathrm{dm}^{3}$ (tab. 1-6). Wartości te posłużyły do sporządzenia krzywych obrazujących zależność mętności oczyszczanych wód złożowych: Ł-1, K-18H, J-8K i ŚW-4 od dawki preparatu bentonitowego DuoBent 1 (rys. 4). Nie zaleca się stosowania jednej jednostki przeliczeniowej do wszystkich rodzajów wód z uwagi na to, że przenikanie światła przez próbkę nie zależy tylko od masy zawiesiny, ale też od geometrii cząstek, ich uwodnienia oraz wpływu innych składników badanego roztworu.

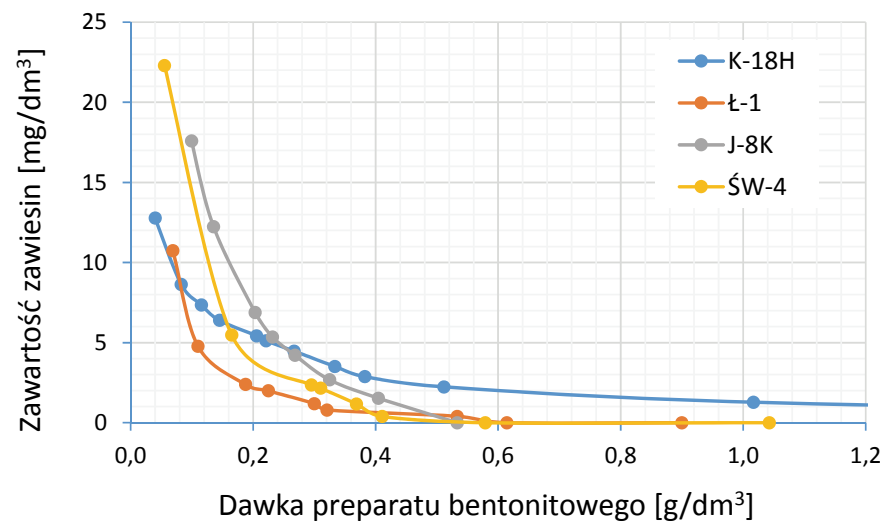

Rys. 4. Zależność mętności oczyszczonych wód złożowych od dawki preparatu bentonitowego DuoBent 1

Fig. 4. The dependence of the turbidity of the treated reservoir waters on the dose of DuoBent 1

$\mathrm{Z}$ danych przedstawionych na rysunku 4 wynika, że dawki preparatu bentonitowego DuoBent 1 wprowadzane do wysokozmineralizowanych wód złożowych (Ł-1, J-8K i ŚW-4) celem zminimalizowania ich mętności są bardzo podobne. Dodanie do oczyszczanych wód preparatu bentonitowego w ilościach powyżej $0,6 \mathrm{~g} / \mathrm{dm}^{3}$ powoduje całkowite usunięcie z nich zawiesin (mętność FAU = 0). Dla osiągnięcia mętności poniżej $2 \mathrm{mg} / \mathrm{dm}^{3}$ (5 FAU) należy zastosować dawki powyżej $0,2 \mathrm{~g} / \mathrm{dm}^{3}$.

W przypadku wody K-18H, która w dużej mierze jest wodą kondensacyjną (niskozmineralizowaną), ilość potrzebnej do jej wyklarowania dawki preparatu bentonitowego DuoBent 1 jest znacznie wyższa. Pełne wyklarowanie oczyszczanej wody wymaga dawki ponad $2,5 \mathrm{~g} / \mathrm{dm}^{3}$, natomiast do osiągnięcia mętności poniżej $2 \mathrm{mg} / \mathrm{dm}^{3}$ (5 FAU) dawka preparatu bentonitowego wynosi około $0,62 \mathrm{~g} / \mathrm{dm}^{3}$ (rys. 4).

Mniejsza efektywność usuwania zawiesin z wody K-18H wynikać może zarówno z jej niskiej mineralizacji, jak i z bardzo wysokiej zawartości niejonowych środków powierzchniowo czynnych (nSPCz). W związku z tym, że istnieje ścisły związek między właściwościami cząstek balastowych a wytrzymałością flokuł, zachodzi przypuszczenie, że obecność w oczyszczanych wodach surfaktantów obniża efektywność prowadzonego procesu.

Wyniki przedstawionych w artykule badań wykazały wysoką efektywność oczyszczania wód złożowych z zawiesin na drodze flokulacji balastowej, w której jako substancję balastującą zastosowano preparat bentonitowy DuoBent 1.

\section{Podsumowanie}

1. W artykule przedstawiono zagadnienia $\mathrm{z}$ zakresu technik stosowania materiałów obciążeniowych w procesie oczyszczania wód, będącym etapem ich przygotowania do magazynowania w warstwach chłonnych.

2. Maksymalne wykorzystanie pojemności złoża do składowania odpadowych wód złożowych wymaga ciągłego monitorowania procesu zatłaczania, $\mathrm{w}$ tym kontroli i modyfikacji podstawowych parametrów zatłaczanych wód, szczególnie zawartości zawiesin, będących przyczyną kolmatacji strefy przyodwiertowej złoża.

3. Zastosowanie preparatu bentonitowego DuoBent 1 podczas oczyszczania wód złożowych z zawiesin w procesie flokulacji balastowej wpływa na wysoką efektywność ich oczyszczania.

4. Przedstawione w artykule wyniki prac laboratoryjnych sugerują obiecujące efekty technologiczne po wdrożeniu tej prostej i skutecznej metody oczyszczania wód złożowych.

Artykuł zrealizowany na podstawie pracy statutowej pt. Badania możliwości zastosowania materiatów obciażajacych do wspomagania oczyszczania wód złożowych - praca INiG - PIB na zlecenie MNiSW; nr zlecenia: 0067/KE/2020, nr archiwalny: DK-4100-0055/2020.

\section{Literatura}

Ahmad A., van der Wal A., Bhattacharya P., van Genuchten C.M., 2019. Characteristics of $\mathrm{Fe}$ and $\mathrm{Mn}$ bearing precipitates generated by $\mathrm{Fe}(\mathrm{II})$ and $\mathrm{Mn}(\mathrm{II})$ co-oxidation with $\mathrm{O}_{2}, \mathrm{MnO}_{4}$ and $\mathrm{HOCl}$ in the presence of groundwater ions. Water Research, 161: 505-516. DOI: 10.1016/j. watres.2019.06.036.

Al Dwairi R.A., Al-Rawajfeh A.E.: 2012. Removal of cobalt and nickel from wastewater by using Jordan low-cost zeolite and bentonite. Journal of the University of Chemical Technology and Metallurgy, 47(1): 69-76. 
Al-Qunaibit M.H., Mekhemer W.K., Zaghloul A.A., 2005. The adsorption of $\mathrm{Cu}$ (II) ions on bentonite - a kinetic study. Journal of Colloid and Interface Science, 283(2): 316-321. DOI: 10.1016/j.jcis.2004.09.022.

Bache D.H., Gregory R., 2007. Flocs in Water Treatment. IWA Publishing: 1-296. ISBN-13: 978-1843390633.

Bottero J.Y., Tchoubar D., Axelos M.A.V., Quienne P., Fiessinger F., 1990. Flocculation of silica colloids with hydroxy aluminum polycations. Relation between floc structure and aggregation mechanisms. Langmuir, 6: 596-602. DOI: 10.1021/la00093a014.

Córdoba P., Liu Q., Garcia S., Maroto-Valer M., 2016. Understanding the importance of iron speciation in oil-field brine $\mathrm{pH}$ for $\mathrm{CO}_{2}$ mineral sequestration. Journal of $\mathrm{CO}_{2}$ Utilization, 16: 78-85. DOI: 10.1016/j. jcou.2016.06.004.

Desjardins C., Koudjonou B., Desjardins R., 2002. Laboratory study of ballasted flocculation. Water Research, 36(3): 744-754. DOI: 10.1016/S0043-1354(01)00256-1

Gantzer P.A., Bryant L.D., Little J.C., 2009. Controlling soluble iron and manganese in a water-supply reservoir using hypolimnetic oxygenation. Water Research, 43: 4285-4294. DOI: 10.1016/j. watres.2008.12.019.

Gasperi J., Laborie B., Rocher V., 2012. Treatment of combined sewer overflows by ballasted flocculation: Removal study of a large broad spectrum of pollutants. Chemical Engineering Journal, 211-212: 293-301. DOI: 10.1016/j.cej.2012.09.025.

Gorin K.V., Sergeeva Y.E., Butylin V.V., Komova A.V., Pojidaev V.M., Badranova G.U., Shapovalova A.A., Konova I.A., Gotovtsev P.M., 2015. Methods coagulation/flocculation and flocculation with ballast agent for effective harvesting of microalgae. Bioresource Technology, 193: 178-184. DOI: 10.1016/j.biortech.2015.06.097.

Guimarães A. de M.F., Ciminelli V.S.T., Vasconcelos W.L., 2009. Smectite organofunctionalized with thiol groups for adsorption of heavy metal ions. Applied Clay Science, 42(3-4): 410-414. DOI: 10.1016/j. clay.2008.04.006.

Hem J.D., 1989. Study and interpretation of the chemical characteristic of natural water. U.S. Geological Survey Water-Supply Paper 2254. <https://pubs.usgs.gov/wsp/wsp2254/pdf/wsp2254a.pdf> (dostęp: 08.09.2020).

Jahed E., Khodaparast M.H.H., Khaneghah A.M., 2014. Bentonite, temperature and $\mathrm{pH}$ effects on purification indexes of raw sugar beet juice to production of inverted liquid sugar. Applied Clay Science, 102: 155-163. DOI: 10.1016/j.clay.2014.09.036.

Jakubowicz P., Steliga T., 2017. Efektywność działania nowoczesnych koagulantów glinowych w warunkach obniżonego $\mathrm{pH}$ wód $\mathrm{z}$ formacji łupkowych. Nafta-Gaz, 3: 169-176. DOI: 10.18668/NG.2017.03.04.

Jakubowicz P., Steliga T., Bąk W., 2008. Analiza wpływu wytypowanych zanieczyszczeń na proces zatłaczania wód złożowych i ścieków do horyzontów chłonnych. Wiertnictwo, Nafta, Gaz, 25: 813-820.

Janocha A., Kluk D., 2005. Aspekty chemizmu zatłaczania wód kopalnianych do horyzontów chłonnych. Miesięcznik WUG. Bezpieczeństwo pracy i ochrona środowiska $w$ górnictwie, 11: 17-21.

Jarvis P., Buckingham P., Holden B., Jefferson B., 2009. Low energy ballasted flotation. Water Research, 43(14): 3427-3434. DOI: 10.1016/j. watres.2009.05.003.

Johnson K.L., McCann C.M., Wilkinson J.L., Jones M., Tebo B.M., West M., Elgy Ch., Clarke C.E., Gowdy C., Hudson-Edwards K.A., 2018. Dissolved $\mathrm{Mn}$ (III) in water treatment works: Prevalence and significance. Water Research, 140: 181-190. DOI: 10.1016/j. watres.2018.04.038.

Khenifi A., Zohra B., Kahina B., Houari H., Zoubir D., 2009. Removal of 2,4-DCP from wastewater by CTAB/bentonite using one-step and two-step methods: A comparative study. Chemical Engineering Journal, 146(3): 345-354. DOI: 10.1016/j.cej.2008.06.028.

Kim H.S., Lamarche C., Verdier A., 1982. Flocculation of Bentonite by non Ionic Polyelectrolyte: Influence of Cations. Studies in Environmental Science, 19: 101-113. DOI: 10.1016/S0166-1116(08)71164-6.

Kluk D., 2011. Badania procesu mieszania wód zatłaczanych z wodami złożowymi o zróżnicowanych potencjałach elektrochemicznych. Nafta-Gaz, 2: 98-106.

Kluk D., 2020. Badania kompatybilności wód złożowych z utworów cechsztynu i czerwonego spągowca w aspekcie zatłaczania do warstw chłonnych. Nafta-Gaz, 7: 474-483. DOI: 10.18668/NG.2020.07.06.

Koppenol W.H., Hider R.H., 2019. Iron and redox cycling. Do's and don'ts. Free Radical Biology and Medicine, 133: 3-10. DOI: 10.1016/j.freeradbiomed.2018.09.022.

Lapointe M., Barbeau B., 2016. Characterization of ballasted flocs in water treatment using microscopy. Water Research, 90: 119-127. DOI: 10.1016/j.watres.2015.12.018.

Lee K.E., Norhashimah M., Teng T.T., Poh B.T., 2012. Development, characterization and the application of hybrid materials in coagulation/ flocculation of wastewater: a review. Chemical Engineering Journal, 203: 370-386. DOI: 10.1016/j.cej.2012.06.109.

Lubaś J., 2013. O potrzebie bardziej dynamicznego wdrażania metod wspomagania wydobycia ropy naftowej z krajowych złóż. NaftaGaz, 10: 744-750.

Munger Z.W., Carey C.C., Gerling A.B., Hamre K.D., Doubek J.P., Klepatzki S.D., McClure R.P., Schreiber M.E., 2016. Effectiveness of hypolimnetic oxygenation for preventing accumulation of $\mathrm{Fe}$ and $\mathrm{Mn}$ in a drinking water reservoir. Water Research, 106: 1-14. DOI: 10.1016/j.watres.2016.09.038.

Nadella M., Sharma R., Chellam S., 2020. Fit-for-purpose treatment of produced water with iron and polymeric coagulant for reuse in hydraulic fracturing: Temperature effects on aggregation and highrate sedimentation. Water Research, 170: 115330. DOI: 10.1016/j. watres.2019.115330.

Ozcan A., Omeroğlu C., Erdoğan Y., Ozcan A.S., 2007. Modification of bentonite with a cationic surfactant: An adsorption study of textile dye Reactive Blue 19. Journal of Hazardous Materials, 140(1-2): 173-179. DOI: 10.1016/j.jhazmat.2006.06.138.

Tzoupanos N.D., Zouboulis A.I., 2011. Preparation, characterisation and application of novel composite coagulants for surface water treatment. Water Research, 45(12): 3614-3626. DOI: 10.1016/j. watres.2011.04.009.

Young J.C., Edwards F.G., 2003. Factors affecting ballasted flocculation reactions. Water Environment Research, 75(3): 263-272. DOI: $10.2175 / 106143003 X 141051$.

Zafisah N.S., Ang W.L., Mohammad A.W., Hilal N., Johnson D.J., 2020. Interaction between ballasting agent and flocs in ballasted flocculation for the removal of suspended solids in water. Journal of Water Process Engineering, 33: 1-6. DOI: 10.1016/j.jwpe.2019.101028.

Zhang Z., Nong H., Li Y., Zhao L., Gao H., 2020. Effects of ballasting particles on settling rate of iron ore tailings. Particulate Science and Technology, 38(4): 427-432. DOI: 10.1080/02726351.2018.1558320.

Zhou Z., Yang Y., Li X., Gao W., Liang H., Li G., 2012. Coagulation efficiency and flocs characteristics of recycling sludge during treatment of low temperature and micro-polluted water. Journal of Environmental Sciences, 24(6): 1014-1020. DOI: 10.1016/S1001-0742(11)60866-8.

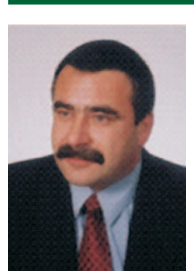

Dr Andrzej JANOCHA

Adiunkt w Zakładzie Technologii Eksploatacji

Płynów Złożowych

Instytut Nafty i Gazu - Państwowy Instytut Badawczy ul. Lubicz 25 A

31-503 Kraków

E-mail: andrzej.janocha@inig.pl

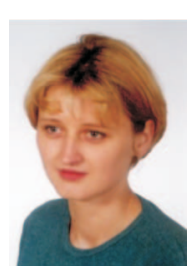

Dr inż. Dorota KLUK

Adiunkt w Zakładzie Technologii Eksploatacji Płynów Złożowych

Instytut Nafty i Gazu - Państwowy Instytut Badawczy ul. Lubicz 25 A

31-503 Kraków

E-mail:dorota.kluk@inig.pl 